\title{
A hallgatói magatartásformák megjelenése és változásának folyamata a Nemzeti Közszolgálati Egyetem „Vírus 2019" Közös Közszolgálati Gyakorlatán
}

KOVÁCS Gábor ${ }^{1}-$ PESTI Tünde ${ }^{2}$ - TŐZSÉR Erzsébet ${ }^{3}$

\begin{abstract}
A Nemzeti Közszolgálati Egyetem minden évben megrendezi a Közös Közszolgálati Gyakorlatot a hallgatói számára. A gyakorlat lehetővé tette a szervezeti önkéntes magatartás (OCB) dimenzióinak és az együttmúködési készség mérését, amelyek elengedhetetlenek a modern közigazgatásban dolgozók számára. A longitudinális kutatás 2019 januárja és májusa között zajlott. A kutatás keretében a gyakorlaton részt vevő teljes hallgatói létszámot vizsgáltuk (886 fö). Az alábbi csoportokat vizsgáltuk: férfi/nö, hivatásos/civil, generációk ( $X, Y, Z)$. A kutatás során az OCB-dimenziók, az együttmüködés és versengés viselkedésmintákat mértük kérdőívek használatával. Az adatokat SPSS 25. verziójával elemeztük ki. Az eredmények többségében nem mutattak szignifikáns eltérést a viselkedés mintázatokban a gyakorlat előtt és alatt, mindazonáltal az eltérések kimutathatók voltak. A legnagyobb különbséget a generációk között és az OCB „elözékenység” dimenziója esetében mértük.
\end{abstract}

Kulcsszavak: Közös Közszolgálati Gyakorlat, szervezeti önkéntes magatartás (OCB), együttmúködés, közigazgatás, rendészet, generációk

\section{Bevezetés}

Jelen tanulmány célja a Nemzeti Közszolgálati Egyetem egyik egyedülálló kooperatív oktatási módszere, az Egyetemi Közös Közszolgálati Gyakorlat (továbbiakban: KKGY vagy gyakorlat) során a hallgatói magatartás vizsgálatát célzó kutatás folyamatának

KOVÁCS Gábor dr., prof., r. dandártábornok, oktatási rektorhelyettes, tanszékvezető egyetemi tanár, Nemzeti Közszolgálati Egyetem Rendészettudományi Kar Rendészeti Vezetéstudományi Tanszék.

Gábor KOVÁCS Prof. Dr., police brigadiel-general, vice rector, professor and head of department, National University Public Service, Faculty of Law Enforcement,

https://orcid.org/0000-0002-1699-827X, kovacs.gabor@uni-nke.hu

2 PESTI Tünde, Nemzeti Közszolgálati Egyetem, Rendészettudományi Doktori Iskola, doktoranduszhallgató. Tünde PESTI, National University of Public Service, Doctoral School of Law Enforcement, PhD student.

https://orcid.org/0000-0003-1211-7890, pesti.tunde1@gmail.com

3 TŐZSÉR Erzsébet, Nemzeti Közszolgálati Egyetem, Rendészettudományi Doktori Iskola, doktoranduszhallgató Erzsébet TŐZSÉR, National University of Public Service, Doctoral School of Law Enforcement, PhD student.

https://orcid.org/0000-0002-3506-1861, tozsererzsebet@gmail.com 
és eredményeinek bemutatása, ${ }^{4}$ amelyre 2019 áprilisában a „VÍRUS 2019” elnevezésű gyakorlat előkészítése és végrehajtása alatt került sor. A gyakorlat előkészítésének és levezetésének folyamatába épített kutatás keretében megtörtént a hallgatók szervezeti önkéntes magatartásának vizsgálata - Organ öt dimenziójának alapulvételével és kérdőívének adaptálása segítségével -, amelyet esetünkben kiegészítettünk az együttmúködés és versengés dimenzióival is.

A KKGY megvalósításával nemcsak a képzés során elsajátított szakmai ismeretek ellenőrzése, hanem a hallgatók szervezeti önkéntes magatartásának és együttmúködésének a mérése is lehetővé vált, ami a képzés során egyébként rejtve maradt. A gyakorlatra minden évben egyszer kerül sor, közel 1000 hallgató részvételével, amelynek során mind a szakmai tudás, mind a különböző szintű szervezetek vezetése is modellezhetővé vált. A KKGY tulajdonképpen egy lehetséges jövőbeli, szakmai, szervezeteken belüli és egymás közötti, több szintű együttmúködést szimulál a hallgatók részvételével, ahol komplex szakmai feladatok végrehajtásán keresztül a hallgatóknak egy adott kihívásra - a gyakorlat fő témájára, amelyre a feladatok épülnek -kell reagálniuk és szakmai felkészültségüket bemutatniuk.

Az előkészítést az Egyetemi Kidolgozó Csoport végezte, amelyet az oktatási rektorhelyettes koordinált. A csoport tagjai nagyfokú szakmai tudással, tapasztalattal, magas szintű szervezőkészséggel és vezetési ismeretekkel, valamint széles körű rálátással rendelkeztek mind a saját szakterületükre, mind pedig a végrehajtó államigazgatási szervek együttmúködésére vonatkozóan.

A gyakorlat menete szerint felvázolásra kerül egy kockázatot jelentő, kialakulóban lévő rendkívüli helyzet (például természeti katasztrófák: „Vadvíz 2013”, "Vihar 2016”, 6 váratlan fegyveres támadás: „Végvár 2014” és „Végvár 2015”, 7 migrációs válsághelyzet: „Vándor 2017”, 8 kibertámadás: „Integrált védelem 2018”9), amely széleskörűen érinti a különböző irányító és végrehajtó államigazgatási szerveket (kormány, minisztérium, államigazgatás, rendészet, valamint honvédség központi, területi és helyi szervezetei). A törvényi szabályozás ilyen esetekben lehetővé teszi ideiglenes szervezeti elemek létrehozását is, így lehetségessé válik műveleti törzsek létrehozása, ez által lehetővé válik azok irányításának, a feladatok koordinálásának gyakorlása is.

A feladatok végrehajtása és megoldása során a hallgatók számára lehetővé válik a képzés során elsajátított elméleti ismeretek gyakorlati alkalmazása, az érintett szervezetek rendkívüli helyzetekben végrehajtandó protokolljainak begyakorlása, egyrészt saját élményt biztosítva a hallgatóknak, másrészt a szakmai tudás mellett átadva a hivatásrendek együttmúködésének értékeit is. A KKGY nagyszabású levezetése szakmai és nevelési célokat is kitűz maga elé. ${ }^{10}$ A Közös Közszolgálati Gyakorlat nagymértékben

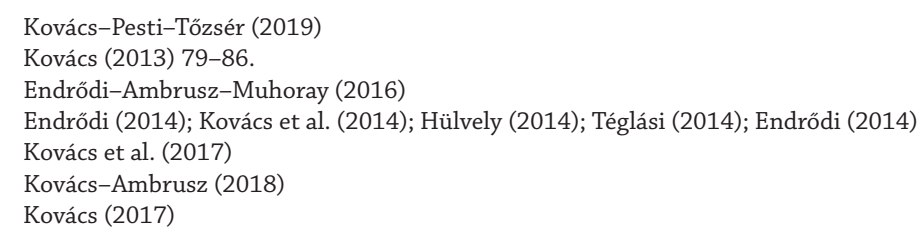


hozzájárul az Egyetemi oktató nevelő munka céljához, a közszolgálati szakemberek magas színvonalú képzéséhez.

A KKGY történetében a „VÍRUS 2019” volt az első olyan gyakorlat, amelynek keretében egy olyan kutatás zajlott, ami a hallgatói magatartásra, nem pedig a szakmai ismeretanyag elmélyítésének mérésére vonatkozott.

A „VÍRUS 2019” gyakorlat központi témája az emberre és az emlősökre veszélyes járvány terjedésének megakadályozása, a kialakult helyzet kezelése volt. Szabolcs-Szatmár-Bereg Megye és Békés Megye bizonyos részein egy vírus ismeretlen törzse jelent meg, amely földrajzilag jól behatárolható területen pusztította az emlős haszonállatállományt. A vírus emberekre is veszélyt jelentett, több esetben súlyos megbetegedés is történt. Feltehetően bioterrorizmus indíttatású cselekmény hatására jelentek meg a járványgócok ebben a két megyében. A járvány bekövetkezésére történő felkészülés során, modellezésre került a törvényalkotási folyamat, a rendőrség, a honvédség, a katasztrófavédelem közös alkalmazása, a veszélyhelyzet kihirdetésének előkészítési folyamata, a veszélyhelyzet bevezetésével kapcsolatos eljárások. Emellett a kormány, a különböző bizottságok, a BM, a HM, a Katasztrófavédelem, a polgármesteri hivatalok, az Országos Vízügyi Főigazgatóság és a megyei szervezetek, Országos Közegészségügyi Intézet, a Fővárosi Vízművek, a MAVIR, a MÁSZ, az ANTSZ, a MÁV, a Volán, a BKV, a NÉBIH, az EMMI, az Agrárminisztérium, az Állatorvostudományi Egyetem, karitatív szervezetek és más együttmúködők bevonására is sor került. ${ }^{11}$

A kutatás során a hallgatói viselkedés került tanulmányozásra, a kutatás fókuszába helyezve az önkéntes szervezeti magatartás (Organisational Citizenship Behaviour, a továbbiakban: $O C B$ ) jellemzőit és az együttmúködést. Ahogyan az angol elnevezés is mutatja, a „szervezeti polgár”, ${ }^{12}$ úgy tekint magára mint a szervezetnek egy elkötelezett polgárára, mintha a szervezet egy állam vagy kisváros lenne, amelynek a sikeres működése egyben a benne élő polgárok sikere is. Tehát ezek olyan magatartásformák, amelyek a szervezeti szerepkör által a személyek számára nem előírtak, sőt elmaradásukat sem kísérheti rosszallás vagy büntetés. Az, hogy mozgósítsák a szervezet tagjait az önkéntes magatartás ilyen formáiba, ez a követelmény elengedhetetlen a sikeres szervezetek vonatkozásában is.

Organ könyvében (Organisational citizenship behaviour: The good soldier syndrome) úgy írja le az OCB fogalmának alapját, amely szerint a szervezeti önkéntes magatartás körébe tartoznak „olyan egyéni, önkéntes viselkedések, amelyek a formális jutalmazási rendszer által sem közvetve, sem közvetlenül nem elismertek, de együttesen elősegítik a szervezet hatékony müködését". ${ }^{13}$

Amennyiben megköveteljük, hogy az OCB egyik kritériuma legyen a szervezeti hatékonyság, akkor meg kell említeni, hogy mit értünk szervezeti hatékonyság alatt,

\footnotetext{
Kovács-Ambrusz (2019)

12 Klein (2016)

13 Organ (1988) A magyar szakirodalom az „önkéntes” kifejezést, Organ a könyvében a saját belátás szerinti, szabadrendelkezésű, „diszkrecionális” kifejezést használja. A továbbiakban a magyar szakirodalom általi önkéntes kifejezést használjuk.
} 
vagy legalább meg kell fogalmaznunk, hogy mit tartunk hatékony vagy nem hatékony szervezetnek. Organ véleménye szerint a hatékony szervezet az, ahol az erőforrások késztermékké vagy szolgáltatássá való átalakítása során pazarlás nélkül képes versenyképes vagy szociális szempontból is elfogadható árut vagy szolgáltatást előállítani. Természetesen más szempontok is szerepet játszhatnak egy szervezet hatékonyságának megállapításában, főként a közigazgatási szerveknél, amelyek nem piaci, profittermelő típusú szervezetek, így például innovációs képesség, rugalmasság, vagy a rendészeti szervek esetében a hatékonyság fokmérője lehet az, hogy mennyire képes a társadalom számára a biztonság szavatolását megteremteni, vagy például a rendvédelmi tisztekkel szemben támasztott főbb követelmények hogyan és mennyire érvényesülnek a szervezetnél. ${ }^{14}$

Organ részben saját, részben mások kutatásai alapján ${ }^{15}$ az OCB-n belül öt kategóriát alkotott: önzetlenség, sportszerűség, lelkiismeretesség, előzékenység, polgári erény.

Figyelembe véve, hogy Organ volt, aki először empirikusan mérhetővé tette a fenti viselkedéseket, egyetértve Singh és Singh ${ }^{16}$ megállapításával, hogy Organ kutatásának van a leghosszabb történelme, ő és kollégái azóta is több cikket és könyvfejezetet írtak az OCB területén, továbbá kutatásaikat több kutató megismételte világszerte és igazolta, jelen kutatásban is Organ dimenzióit használtuk fel.

Tekintettel arra, hogy a kutatásban részt vevő hallgatók eltérő generációkhoz tartoznak a generációs sajátosságok is figyelembe voltak véve az alábbiak szerint:

Mannheim (1952) definíciója szerint az adott időintervallumban született egyének csoportját nevezzük generációnak, akiket életük során közel azonos történelmi és szociokulturális környezeti hatások értek. ${ }^{17}$ Vagyis a hasonló meghatározó élmények hatására, hasonló attitűdök és működésmódok jellemzik az adott korosztályt. Így bár egy meglehetősen leegyszerúsített tipológiát alkalmazunk az emberek adott csoportjának tulajdonságainak feltérképezéséhez, de a kutatások számos esetben bizonyították a generációs megközelítés létjogosultságát a társadalomkutatások során. A kutatásban részt vevők életkor alapján az X, Y és $Z$ generációhoz tartoznak, így jelen írásban csak ezekkel foglalkozunk.

Az 1965 és 1979 között születetteket tekintjük X generációnak Coupland regénye nyomán elnevezve, ők a digitális bevándorlók, hiszen már felnőttként ismerkedtek az internettel és a digitális fejlődéssel. ${ }^{18} \mathrm{~A}$ kulcsos gyerekek korosztálya, mert mindkét szülő dolgozott, és/vagy csonkacsalád gyermekeként nőttek fel. A tévé és a videojátékok megjelenése befolyásolta fejlődésüket fiatal felnőttként, így gondolkodásuk már inkább vizuális, képi, ellentétben a baby boomerek ${ }^{19}$ verbális fókuszával. Mindent megtesznek a sikerért, tudják, hogy ehhez gyorsan kell reagálniuk, jónak kell lenniük

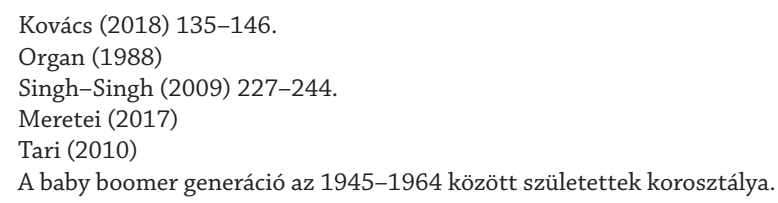


szakmailag, ezért képzettek, és sokat dolgoznak, hogy karriert építsenek. A rendszerváltás után az egzisztenciális szorongás, ami elől menekültek, szerves részét képezi mindennapjaiknak. ${ }^{20}$ Fő motivációjuk megoldani dolgokat, megcsinálni, kevesebből többet létrehozni, fontos számukra a státusz és a pénz megszerzése.

Az 1980 és 1995 között születettek az Y generációhoz tartozók vagy az első digitális bennszülött korosztály, hiszen őket még tinédzserként érte az internet megjelenése, tökéletesre fejlesztették a számítógép és a mobiltelefonok használatát. A baby boomer verbális, és az X generáció képi gondolkodása helyett, őket az akció, a „multitasking” jellemzi. Fő mozgatórugójuk fejlődni, tökéletesíteni a képességeiket, alkalmazkodni, bizonyítani rátermettségüket. Megtapasztalják a 2001. szeptember 11. utáni krízisperiódust, tanulnak még, vagy kezdő munkavállalók a gazdasági világválság idején, szorongásteli életet élnek.

A Z generációhoz soroljuk a 1996 és 2010 között születetteket. Az első igazi digitális bennszülött generáció, hiszen az internet az ő életükben mindig is létezett, tanulniuk sem kellett a használatát, egyszerủen beleszülettek. Virtuális közösségi életet élnek, emiatt kicsit elveszettek az offline szociális világban, kevesebb a konfliktuskezelési gyakorlatuk. ${ }^{21}$ Jelenlegi életkori sajátságuk miatt még sokan közülük az identitáskeresés fázisát élik. ${ }^{22}$ Fő motivációjuk hatni, a világot jobbá tenni. Az Y generációsokat jellemző multitasking még inkább jellemző, figyelmük terjedelme lecsökken, nagyon hamar elunnak dolgokat, helyzeteket, türelmetlenebbek. ${ }^{23}$ Figyelmük fenntartásához elengedhetetlen az interaktivitás, oktatásuk során szükségük van a tanultak átélésére. $^{24}$

\section{A kutatás dimenziói}

A kutatócsoport feltételezte, hogy a szervezeti önkéntes magatartást mérni lehet a gyakorlat során, így ennek megfelelően a fő kutatási kérdés az volt, hogy milyen öszszefüggést fedezünk fel a hallgatók viselkedésével kapcsolatban, különbözik-e a normál múködésmódjuk, viselkedésük az együttműködést szimuláló, gyakorlati helyzetben tanúsított viselkedésüktől.

A gyakorlat eredeti célkitűzése az volt, hogy lehetőséget biztosítson az elméletben elsajátított ismeretek integrálására és a gyakorlatban való alkalmazásának kipróbálására, továbbá a gyakorlat - hasonlóan, mint a képzés - az azon részt vevő hallgatók számára egyfajta előszocializáció is a választott hivatásukhoz és a későbbi szakmai együttmüködéshez. A longitudinális kutatás keretében két időpontban - a gyakorlat előkészítése és végrehajtása során - átfedéses vizsgálattal mértük a hallgatók viselkedését az Organ

\footnotetext{
Tari (2010)

21 Tari (2010)

22 Törőcsik-Szűcs-Kehl (2014)

23 Tari (2018)

24 Tari (2011)
} 
által alkotott öt dimenzió ${ }^{25}$ mentén, amelyet az együttmúködés és a versengés mérésével is kiegészítettük:

- Önzetlenség/segítőkészség: olyan típusú segítőkész viselkedések, amelyek az egyén önzetlenségéből fakadnak.

- Sportszerûség/elkötelezettség: a szervezet tagja úgy viselkedik, mint egy jó csapatjátékos, egyéni érdekeit a szervezet érdekeivel szemben a háttérbe szorítja, leterheltség esetén is csapatjátékosként viselkedik.

- Lelkiismeretesség: pontosság időbeli és a feladatok végrehajtása során.

- Előzékenység/udvariasság: tekintettel lenni arra, hogy viselkedése, feladatai elvégzése milyen hatással van a többiek feladat-végrehajtására.

- Polgári erény: szervezeten belül polgári erényként értékelendő, ha az egyén azonosul, együtt él a szervezettel, tájékozott és aktívan részt vesz annak életében.

- A fenti magatartásformák mindegyike elengedhetetlen a modern közszolgálat számára, ezért nagyon fontos, hogy az egyetemről kikerülő hallgatók magukévá tudják tenni ezeket a viselkedésmódokat a szervezetbe kerülése előtt, elsajátítsák azokat még az oktatás során.

A fő hipotézisek:

- A két mérés értékei között eltérést tudunk mérni. Vélhetően a hallgatók viselkedésének változása mindegyik dimenzióban pozitív irányban kimutatható lesz a KKGY-t megelőzően és azt követően.

- A csoportok között (nem, szak, kor) eltérés lesz kimutatható, illetve a változás mértéke is eltérő lesz a részt vevő csoportok esetében az első és második mérés értékei között. Feltételeztük, hogy a gyakorlatot megelőzően is eltérés lesz a csoportok között, illetve a változás mértéke is eltér majd az egyes csoportok esetében.

Ennek vizsgálatához a hallgatók körében az alábbi csoportokat tanulmányoztuk:

- férfi/nő,

- hivatásos/civil,

- generációk (X, Y, Z).

A vizsgálathoz saját, online kérdőívet állítottunk össze, amelyet az Egyetem UniPoll rendszerén keresztül juttatunk el a résztvevőknek. Minden dimenzióhoz 3-3 állítást rendeltünk hozzá, és az egyes dimenziókhoz kapcsolt magatartásformák gyakoriságát 1-5-ig (1: soha, 5: mindig) terjedő Likert-skálán mértük fel.

Megtörtént a gyakorlaton részt vevő teljes állomány vizsgálata, ez jelen esetben a gyakorlaton lévő 886 hallgatót jelentette az alábbiak szerint:

25 Organ (2018) 7-19. 
1. táblázat: A részt vevő hallgatók megoszlása intézményi hovatartozás szerint.

Forrás: a szerzők szerkesztése

\begin{tabular}{|l|c|}
\multicolumn{1}{|c|}{ Kar/karközi intézet } & Hallgatói létszám/fö \\
\hline Rendészettudományi Kar (RTK) & 249 \\
\hline Államtudományi és Közigazgatási Kar (ÁKK) & 210 \\
\hline Hadtudományi és Honvédtisztképző Kar (HHK) & 178 \\
\hline Katasztrófavédelmi Intézet (KVI) & 94 \\
\hline Nemzetközi és Európai Tanulmányok Kar (NETK) & 111 \\
\hline Nemzetbiztonsági Intézet (NBI) & 20 \\
\hline Víztudományi Kar (VTK) & 24 \\
\hline Összesen & 886 \\
\hline
\end{tabular}

A demográfiai adatok körét minimálisra szúkítettük le, a résztvevők személyét azonosító információkat a kérdőív nem tartalmazott, így biztosítva az anonimitást, illetve a kutatás számára a minél őszintébb válaszokat.

Tekintettel arra, hogy könnyen kitölthető, online kérdőív mellett döntöttünk, és biztosítani akartuk azt, hogy a kérdőív mindenki számára egyértelmú fogalmakat, kifejezéseket tartalmazzon, a kialakított kérdőíveket két módszerrel (csoportos interjúkkal, a Magyary Zoltán, a Nemzetközi és Európai, valamint az Ostrakon Szakkollégiumok és önkéntes hallgatók segítségével, továbbá online próbakitöltésekkel) ellenőriztük. A visszajelzéseket és javaslatokat beépítettük a végleges kérdőívbe.

A KKGY végrehajtása során megkértük a közremúködő oktatókat, hogy megfigyelésükkel támogassák a kutatás céljának elérését, erre elsősorban az NKE Oktatási Központban volt lehetőség. Az oktatói megfigyelői kérdőívek hasznos visszajelzésként szolgáltak a hallgatói kérdőívek kiértékelése és értelmezése során, továbbá visszaigazolták Organ megállapítását, hogy a szervezeti önkéntes magatartást külső megfigyeléssel nem lehet elvégezni, mert az nem mutatja meg, hogy az egyén az adott viselkedést belső indíttatásból végzi, nem pedig megfigyelés hatására.

A kutatás során nyert adatokat a kutatócsoport tagjai, jelen tanulmány írói dolgozták fel az erre vonatkozó aktuális érvényes etikai és jogszabályi előírások betartásával.

A mérés ideje szerint megjelölt, egyesített adatbázist az IBM SPSS Statistics 25 verziójával is elemeztük. A kérdőív hét faktorának reliabilitását a Cronbach Alfa értékeikkel vizsgáltuk: 
2. táblázat: A kérdôiv dimenzióinak Cronbach Alfa-értékei. Forrás: a szerzők szerkesztése

\begin{tabular}{|c|c|c|c|c|c|c|c|}
\hline & Önzetlenség & Előzékenység & $\begin{array}{c}\text { Polgári } \\
\text { erény }\end{array}$ & $\begin{array}{c}\text { Sportsze- } \\
\text { rüség }\end{array}$ & Lelkiismeretesség & Versengés & Együttmüködés \\
\hline $\begin{array}{c}\text { Cronbach's } \\
\text { Alpha }\end{array}$ & 0,738 & 0,595 & 0,757 & 0,586 & 0,524 & 0,7 & 0,74 \\
\hline
\end{tabular}

Az önzetlenség esetében ez az érték nagyon magas, hiszen 0,738, tehát a faktorhoz tartozó három állítás esetében a válaszok összetartók. Az előzékenység esetében egy kicsit alacsonyabb, 0,595, de egyértelmú az állítások együttjárása. A polgárierény-faktor esetében is magas, 0,757, a Cronbach Alfa-értéke. A sportszerüség szintén alacsonyabb, de még így is magas, 0,586-os értéket mutat. A lelkiismeretesség esetében ez a szám 0,524. A versengés Cronbach Alfa-értéke 0,7, míg az együttmúködésnél 0,74. Tehát a kérdőív reliabilitása magasnak tekinthető mind a hét faktor esetében.

\section{Kitöltési adatok}

Az első mérésre 2019. február 15. és 2019. április 4. között került sor. A második mérés, a KKGY záró napja, 2019. április 16. és 2019. április 23. között zajlott, szintén 886 hallgatónak küldtük ki a kérdőívet.

3. táblázat: A két mérés kitöltési adatai. Forrás: a szerzők szerkesztése

\begin{tabular}{|c|c|c|c|c|}
\hline & \multicolumn{2}{|c|}{ 1. mérés } & 4 & $0,45 \%$ \\
\hline Nem járult hozzá & 6 & $0,68 \%$ & 50 & $5,64 \%$ \\
\hline Nem teljes kitöltés & 25 & $2,82 \%$ & 407 & $45,94 \%$ \\
\hline Teljes kitöltés & 417 & $47,07 \%$ & & \multicolumn{2}{c|}{ 2. més } \\
\hline
\end{tabular}

Az első mérés alkalmával 448 fő töltötte ki a megadott időpontig, ami a KKGY-n részt vevő hallgatók 50,56\%-a. Ebből 417 hallgató töltötte ki teljes egészében a kérdőívet, 25 nem fejezte be a kitöltést, 6 pedig nem egyezett bele a kutatásban való részvételbe, és a többi el sem kezdte a kitöltést.

A második mérés zárásáig 461 fő töltötte ki a kiküldött kérdőívet, ami 52,03\%. A kérdôívek feldolgozásakor ismét kizártuk a nem teljesen kitöltött kérdőíveket (50 fó), és azokat, amelyeknél a hallgatók nem járultak hozzá a kutatásban való részvételhez (4fó). Így 407 kérdőivet tudtunk a második mérés után felhasználni a kutatásunkhoz. 
4. táblázat: A nem szerinti megoszlás a két mérés során. Forrás: a szerzők szerkesztése

\begin{tabular}{|c|c|c|c|c|}
\hline & \multicolumn{2}{|c|}{ 1. mérés } & \multicolumn{2}{c|}{ 2. mérés } \\
\hline Férfi & 195 & $46,76 \%$ & 201 & $49,39 \%$ \\
\hline Nö & 222 & $53,24 \%$ & 208 & $51,11 \%$ \\
\hline Összesen & 417 & & 407 & \\
\hline
\end{tabular}

Az első mérés alkalmával 195 férfi (46,76\%) és 222 női $(53,24 \%)$ hallgató töltötte ki a kérdőívet, a második mérés alkalmával 201 férfi (49,39\%) és 208 nő (51,11\%), tehát a nemi megoszlás szempontjából egészen kiegyenlített a kitöltők aránya.

A civil, illetve hivatásos szakirányú hallgatók arányát az alábbi táblázat mutatja:

5. táblázat: A szakirány szerinti megoszlás a két mérés során. Forrás: a szerzők szerkesztése

\begin{tabular}{|c|c|c|c|c|}
\hline & \multicolumn{2}{|c|}{ 1. mérés } & \multicolumn{2}{c|}{ 2. mérés } \\
\hline Hivatásos & 161 & $38,61 \%$ & 172 & $42,26 \%$ \\
\hline Civil & 256 & $61,39 \%$ & 235 & $57,74 \%$ \\
\hline Összesen & 417 & & 407 & \\
\hline
\end{tabular}

Az első mérés alkalmával a 417 hallgatóból 256 civil és 161 hivatásos szakirányú hallgató töltötte ki a kérdőívet. A második méréskor a 407 hallgatóból 235 civil és 172 hivatásos szakirányú hallgató töltötte ki a kérdőívet.

A karok és karközi intézetek tekintetében az alábbi megoszlást láthatjuk a kitöltők között.

6. táblázat: A kérdốív kitöltési arányai intézményi hovatartozás szerint. Forrás: a szerzök szerkesztése

\begin{tabular}{|l|c|c|c|}
\hline \multicolumn{1}{|c|}{ Kar/Karközi intézet } & $\begin{array}{c}\text { Részt vevö hallgatói } \\
\text { létszám }\end{array}$ & $\begin{array}{c}\text { Kitöltési arány } \\
\text { 1. mérés (\%) }\end{array}$ & $\begin{array}{c}\text { Kitöltési arány } \\
\text { 2. mérés (\%) }\end{array}$ \\
\hline Nemzetközi és Európai Tanulmányok Kar (NETK) & 111 & $74,77 \%$ & $56,75 \%$ \\
\hline Államtudományi és Közigazgatási Kar (ÁKK) & 210 & $71,42 \%$ & $69,04 \%$ \\
\hline Rendészettudományi Kar (RTK) & 249 & $55,02 \%$ & $63,05 \%$ \\
\hline Víztudományi Kar (VTK) & 24 & $25 \%$ & $58,33 \%$ \\
\hline Katasztrófavédelmi Intézet (KVI) & 94 & $24,46 \%$ & $13,82 \%$ \\
\hline Hadtudományi és Honvédtisztképzó Kar (HHK) & 178 & $10,11 \%$ & $8,42 \%$ \\
\hline Nemzetbiztonsági Intézet (NBI) & 20 & $0 \%$ & $0 \%$ \\
\hline
\end{tabular}


Az első kitöltéskor a Nemzetközi és Európai Tanulmányok Kar, valamint az Államtudományi és Közigazgatási Kar hallgatói voltak a legaktívabbak, de kiemelkedőnek értékeljük a Rendészettudományi Kar hallgatói 55,02\%-os kitöltési arányát is.

A második mérés részvételi százalékait tekintve jelentős növekedést láthatunk a Víztudományi Kar és a Rendészettudományi Kar esetében. Az Államtudományi és Közigazgatási Kar, valamint a Rendészettudományi Kar hallgatói voltak a legaktívabbak, de kiemelkedő, 50\% feletti a Nemzetközi és Európai Tanulmányok Kar, továbbá a Víztudományi Kar hallgatói kitöltési részvételi aránya is.

\section{Eredmények}

\section{A két mérés összehasonlítása}

A két mérés közötti eltérést a hét faktor átlagainak összevetésével mutatjuk be az alábbi táblázattal:

7. táblázat: A két mérés során a hét faktor átlagai, szórásai és t-próba eredményei. Forrás: a szerzők szerkesztése

\begin{tabular}{|c|c|c|c|c|}
\hline & Mérés & Átlag & Szórás & $\begin{array}{l}\text { t-próba } \\
\text { (p) }\end{array}$ \\
\hline \multirow{2}{*}{ Önzetlenség } & 1 & 4,1503 & 0,65561 & \multirow{2}{*}{$\begin{array}{r}-1,863 \\
(0,063) \\
\end{array}$} \\
\hline & 2 & 4,2383 & 0,70087 & \\
\hline \multirow{2}{*}{ Előzékenység } & 1 & 3,9936 & 0,69335 & \multirow{2}{*}{$\begin{array}{r}1,635 \\
(0,102)\end{array}$} \\
\hline & 2 & 3,9124 & 0,73255 & \\
\hline \multirow{2}{*}{ Polgári erény } & 1 & 3,2350 & 0,94206 & \multirow{2}{*}{$\begin{array}{r}-2,311 \\
\left(0,021^{*}\right)\end{array}$} \\
\hline & 2 & 3,4161 & 0,95233 & \\
\hline \multirow{2}{*}{ Sportszerủség } & 1 & 3,6675 & 0,66204 & \multirow{2}{*}{$\begin{array}{r}\mathrm{d}=-0,916 \\
(0,360)\end{array}$} \\
\hline & 2 & 3,7117 & 0,72291 & \\
\hline \multirow{2}{*}{ Lelkiismeretesség } & 1 & 3,7034 & 0,67837 & \multirow{2}{*}{$\begin{array}{l}-1,437 \\
(0,151)\end{array}$} \\
\hline & 2 & 3,7723 & 0,69758 & \\
\hline \multirow{2}{*}{ Versengés } & 1 & 3,2414 & 0,67370 & \multirow{2}{*}{$\begin{array}{l}-0,571 \\
(0,568) \\
\end{array}$} \\
\hline & 2 & 3,2695 & 0,73520 & \\
\hline \multirow{2}{*}{ Együttmúködés } & 1 & 4,0903 & 0,64558 & \multirow{2}{*}{$\begin{array}{r}0,412 \\
(0,680)\end{array}$} \\
\hline & 2 & 4,0713 & 0,68177 & \\
\hline
\end{tabular}

Két mintás t-próbával végzett összehasonlítás a két mérés között szignifikáns különbséget csak a polgári erény esetében mutat, ugyanakkor a faktorok többsége mutat növekedést. A két mérés átlagai közti különbségeket az alábbi diagramon ábrázoltuk. 


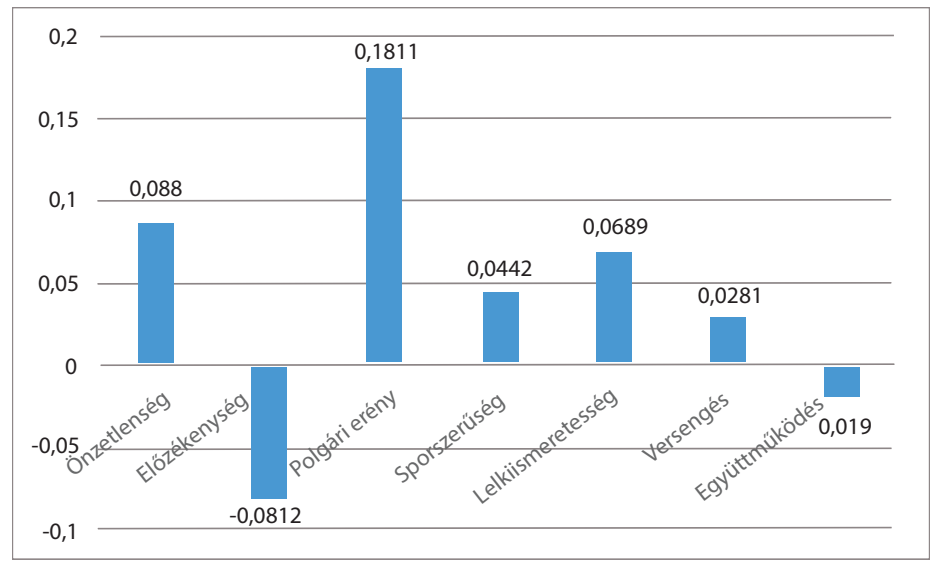

1. ábra: A két mérés átlagai közti különbségek. Forrás: a szerzők szerkesztése

A legnagyobb növekedést a polgári erény esetében látjuk, ami 3,24-ről 3,42-re emelkedett. Ezt követi az önzetlenség (4,15-ről 4,24-re) és a lelkiismeretesség (3,70-ről 3,77-re). Érdekes eredményként azt láthatjuk, hogy 0,08-dal csökkenést mutat az előzékenység (3,99-ről 3,91-re). Ezzel párhuzamosan megfigyelhető a versengés kismértékű növekedése (3,24-ről 3,27-re), és az együttműködés kismértékű csökkenése (4,09-ről 4,07-re) is. Feltételezhetően ennek oka a teljesítményhelyzet okozta változás a társas múködésben, ami rivalizálás formájában jelentkezhet. Mindazonáltal az együttműködés értéke mind az első mérés, mind a második mérés alkalmával magasabb értéket mutat, mint a versengés értéke. Az alábbi diagramokon a kérdőív hét dimenziójához tartozó válaszgyakoriságokat tüntettük fel, a mérés szerinti százalékos megoszlásokban:

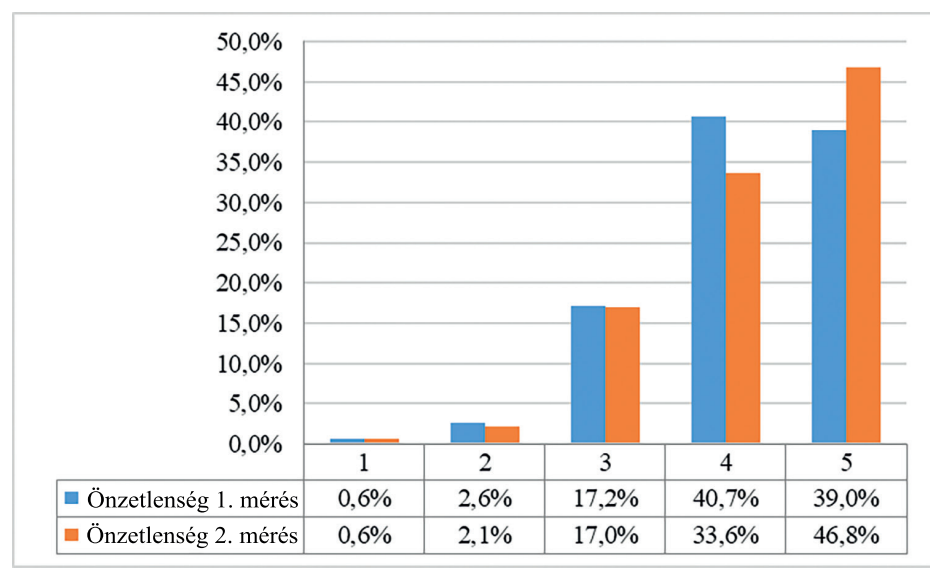

2. ábra: Önzetlenség gyakorisága. Forrás: a szerzők szerkesztése 
Jól látható, hogy az önzetlenség dimenzióban mindkét mérés alkalmával a 4-es és az 5-ös válaszok domináltak, de ha megnézzük a diagramot, láthatjuk a mindig válasz (5) megemelkedett, a soha (1) válasz nem mutatott változást, a 2-es, 3-as válasz csökkent, tehát a közös feladatmegoldást követően 1-5 (soha - mindig) skálán önzetlenebbnek jellemzik a magatartásukat a hallgatók.

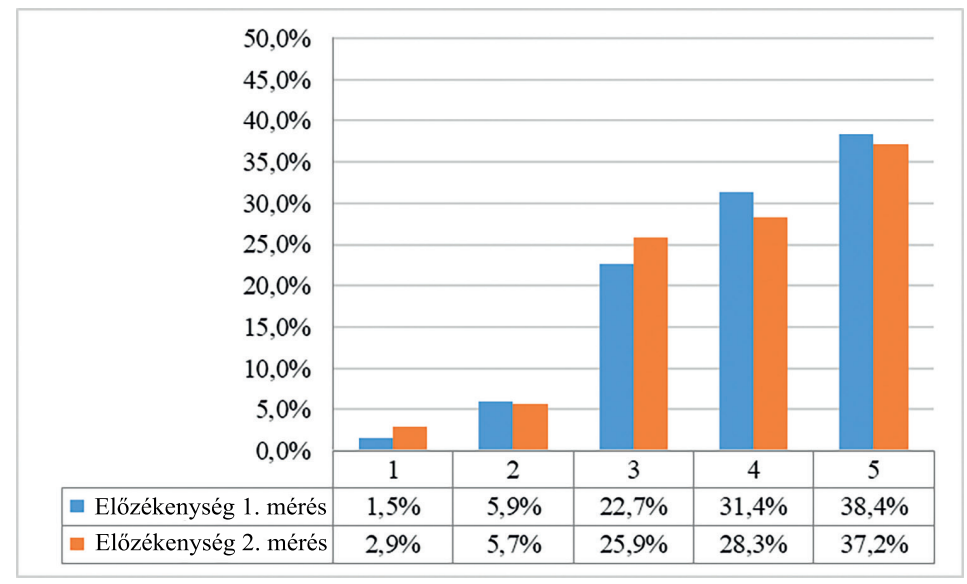

3. ábra: Előzékenység gyakorisága. Forrás: a szerzők szerkesztése

Jól látható, hogy az előzékenység esetében a közepes válasz gyakorisága 22,7\%-ról 25,9\%-ra emelkedik, míg a 4-es és 5-ös válaszok gyakorisága csökkent. Ez a csökkenési tendencia az előzékenységben arra utal, hogy a feladat-végrehajtás során a hallgatók a feladatra fókuszálnak, és nem a társas környezetükre.

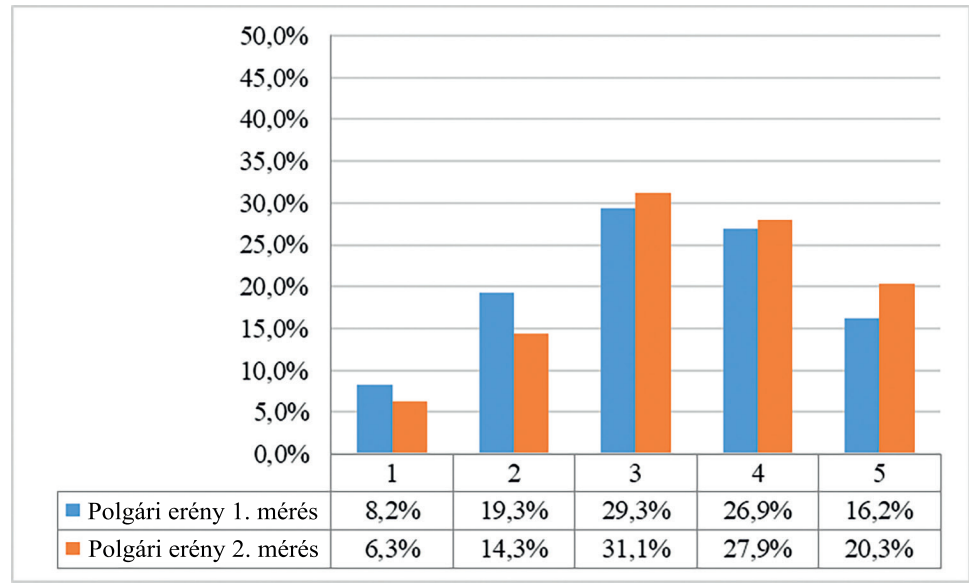

4. ábra: Polgári erény gyakorisága. Forrás: a szerzők szerkesztése 
A polgári erény esetében nem látjuk a mindig irányába mutató szélső értékek felé való tolódást, amely több mutatót is jellemzett az OCB-dimenziói közül, ehelyett a középérték dominál mindkét méréskor. A második mérés eredményei viszont emelkedést mutatnak a 3-as, 4-es és 5-ös válaszok esetében, míg csökkenést az 1-es és 2-es válaszoknál, tehát mondhatjuk, hogy a szervezet felé való elköteleződés magatartásformái a közös feladat-végrehajtás során gyakoribbá válnak.

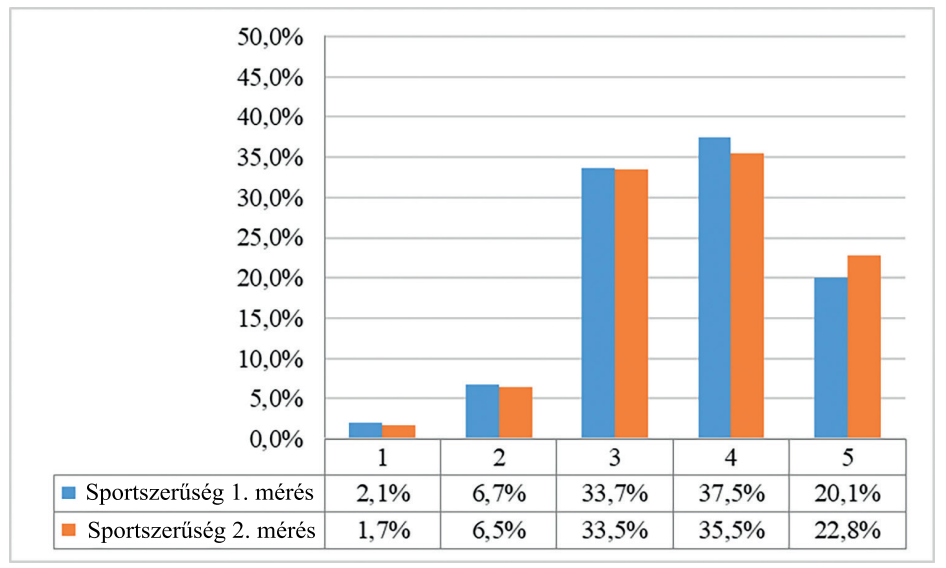

5. ábra: Sportszerüség gyakorisága. Forrás: a szerzôk szerkesztése

A sportszerűség dimenzió esetében a 3-as és a 4-es válaszok dominálnak mindkét méréskor, a közös feladat-végrehajtás után az 5-ös válaszok mutatnak minimális emelkedést, tehát a sportszerüség magatartásformái gyakoriságának értékelésekor kismértékủ emelkedést mutattak.

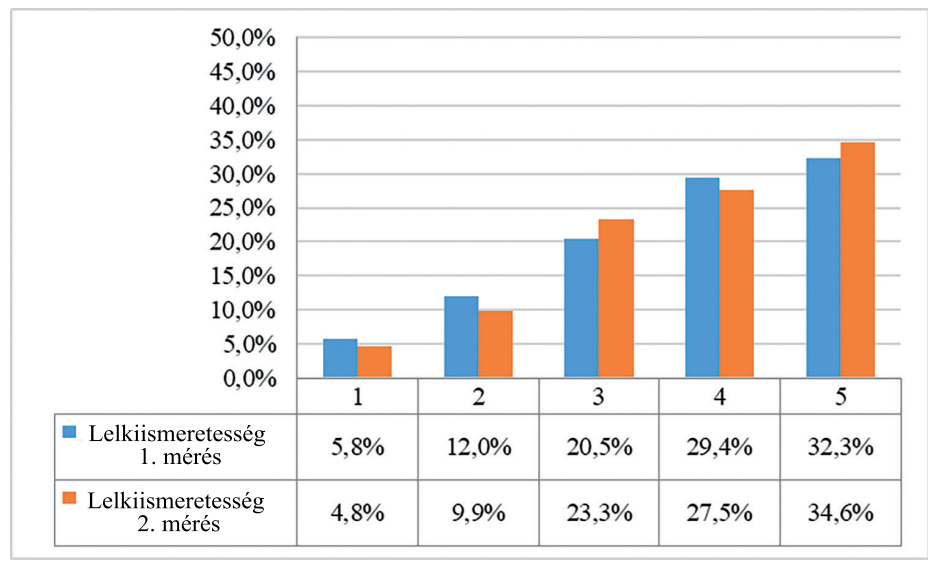

6. ábra: Lelkiismeretesség gyakorisága. Forrás: a szerzök szerkesztése 
A lelkiismeretesség dimenzióban a válaszok gyakorisága az 1-es (soha) választól fokozatos emelkedést mutat az 5-ös (mindig) értékig mindkét mérés esetében. A két mérés között pedig a 3-as és 5-ös válaszok esetében tapasztalunk emelkedést. Tehát a hallgatók alapvetően inkább érzik gyakorinak a lelkiismeretesség magatartásformáit saját viselkedésükben, törekednek a feladatok pontos végrehajtására, a két mérés között enyhe emelkedést mutatnak az átlagolt lelkiismeretesség értékében is.

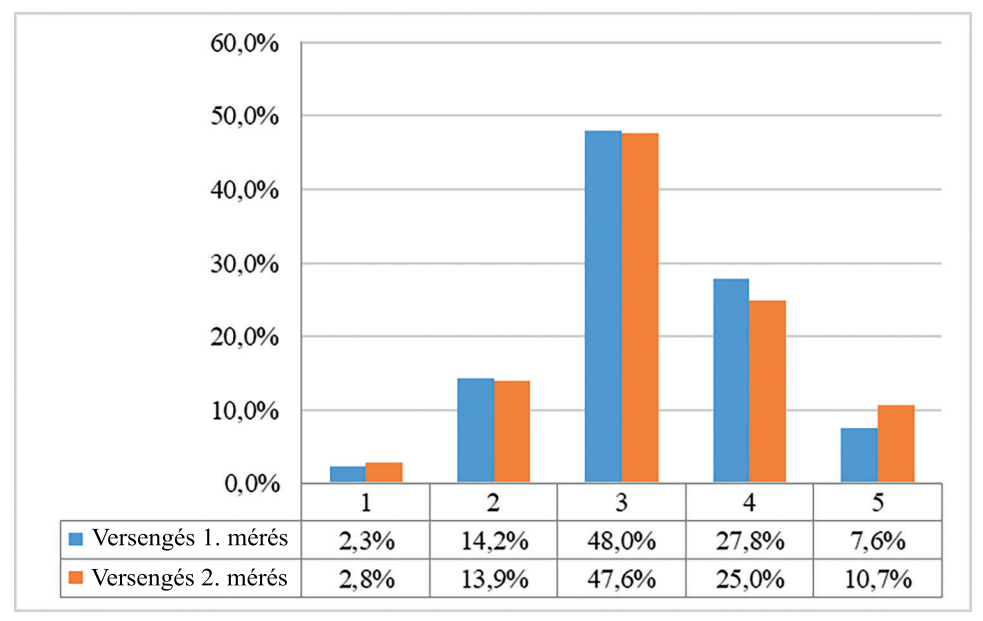

7. ábra: Versengés gyakorisága. Forrás: a szerzök szerkesztése

A versengés esetében a középérték a domináns, majdnem a válaszok felét teszi ki mindkét mérés esetében a 3-as. A válaszadók kevéssé jellemzőnek találják magukra a versengési dimenzióban megfogalmazott viselkedésformákat. A közös feladatmegoldási helyzet hatására látható, hogy az 5-ös (mindig) válasz 3\%-os növekedést mutatott a második méréskor, ami a feladathelyzetben megjelenő rivalizálást, illetve a feladatra való koncentrálást mutathatja. 


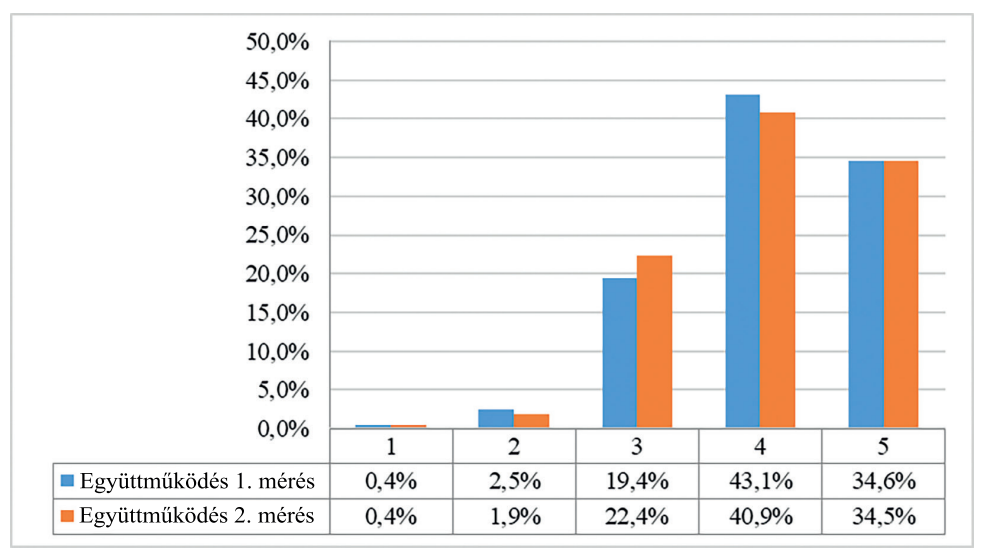

8. ábra: Együttmúködés gyakorisága. Forrás: a szerzők szerkesztése

Az együttmúködés esetében a válaszok gyakoriságában a 4-es és 5-ös túlsúlya a jellemző mindkét mérés esetében, tehát a hallgatók egyértelműen gyakoribbnak vélik magatartásukban az együttmúködési viselkedésformákat. A második mérés alkalmával a 3-as válasz gyakorisága 3\%-os emelkedést mutat, illetve a 4-es kisebb csökkenést, ez látható az átlagértékek enyhe csökkenésében is. Az együttmüködés viselkedési gyakoriság csökkenése szorosan kapcsolódik a versengési viselkedés gyakoribbá válásához, a kettő között fordított arányosság van jelen.

Egyértelmủ a két (versengés, együttmúködés) dimenzió változásából, hogy a közösen végrehajtott feladatot követően a hallgatók figyelme a problémamegoldásra, a feladat végrehajtására összpontosul, és a társas környezet háttérbe szorul. Ez a tendencia magyarázhatja az elózékenység csökkenését és a lelkiismeretesség, valamint versengés növekedését is az együttmúködés magasabb értéke mellett.

\section{A csoportok összehasonlítása}

\section{Nemi megoszlás alapján}

A férfi-nő csoportokat összehasonlítva az első mérés és a második mérés mintájában az alábbi átlagokat kaptuk a faktorokra. 
KOVÁCS Gábor - PESTI Tünde - TŐZSÉR Erzsébet: A hallgatói magatartásformák megjelenése...

8. táblázat: Mérésenként a nem szerinti csoportok átlagai, szórásai és t-próba eredményei. Forrás: a szerző́k szerkesztése

\begin{tabular}{|c|c|c|c|c|c|c|}
\hline & Neme & Mérés & $\mathbf{N}$ & Átlag & Szórás & $\begin{array}{c}\text { t-próba } \\
\text { (p) }\end{array}$ \\
\hline \multirow{14}{*}{ Férfi } & \multirow{2}{*}{ Önzetlenség } & 1 & 195 & 4,1043 & 0,68694 & \multirow{2}{*}{$\begin{array}{l}-1,262 \\
(0,208)\end{array}$} \\
\hline & & 2 & 201 & 4,1924 & 0,70200 & \\
\hline & \multirow{2}{*}{ Előzékenység } & 1 & 195 & 3,8239 & 0,71820 & \multirow{2}{*}{$\begin{array}{r}0,243 \\
(0,808)\end{array}$} \\
\hline & & 2 & 201 & 3,8060 & 0,75089 & \\
\hline & \multirow{2}{*}{ Polgári erény } & 1 & 195 & 3,1641 & 0,99734 & \multirow{2}{*}{$\begin{array}{r}d=-2,250 \\
\left(0,025^{*}\right)\end{array}$} \\
\hline & & 2 & 201 & 3,3930 & 0,96826 & \\
\hline & \multirow{2}{*}{ Sportszerűség } & 1 & 195 & 3,6718 & 0,73020 & \multirow{2}{*}{$\begin{array}{l}-0,703 \\
(0,482)\end{array}$} \\
\hline & & 2 & 201 & 3,7247 & 0,76627 & \\
\hline & \multirow{2}{*}{ Lelkiismeretesség } & 1 & 195 & 3,6308 & 0,72064 & \multirow{2}{*}{$\begin{array}{l}-1,175 \\
(0,241)\end{array}$} \\
\hline & & 2 & 201 & 3,7164 & 0,72935 & \\
\hline & \multirow{2}{*}{ Versengés } & 1 & 195 & 3,2889 & 0,63793 & \multirow{2}{*}{$\begin{array}{l}-1,007 \\
(0,315)\end{array}$} \\
\hline & & 2 & 201 & 3,3566 & 0,69723 & \\
\hline & \multirow{2}{*}{ Együttmúködés } & 1 & 195 & 4,0359 & 0,65573 & \multirow{2}{*}{$\begin{array}{r}0,546 \\
(0,585)\end{array}$} \\
\hline & & 2 & 201 & 3,9983 & 0,70985 & \\
\hline \multirow{14}{*}{ Nő } & \multirow{2}{*}{ Önzetlenség } & 1 & 222 & 4,1907 & 0,62556 & \multirow{2}{*}{$\begin{array}{l}-1,445 \\
(0,149)\end{array}$} \\
\hline & & 2 & 206 & 4,2832 & 0,69856 & \\
\hline & \multirow{2}{*}{ Elôzékenység } & 1 & 222 & 4,1426 & 0,63592 & \multirow{2}{*}{$\begin{array}{l}1,957 \\
(0,51)\end{array}$} \\
\hline & & 2 & 206 & 4,0162 & 0,70057 & \\
\hline & \multirow{2}{*}{ Polgári erény } & 1 & 222 & 3,2973 & 0,88828 & \multirow{2}{*}{$\begin{array}{l}-1,102 \\
(0,271)\end{array}$} \\
\hline & & 2 & 206 & 3,4385 & 0,93834 & \\
\hline & \multirow{2}{*}{ Sportszerüség } & 1 & 222 & 3,6637 & 0,59746 & \multirow{2}{*}{$\begin{array}{l}-0,573 \\
(0,567)\end{array}$} \\
\hline & & 2 & 206 & 3,6990 & 0,67957 & \\
\hline & \multirow{2}{*}{ Lelkiismeretesség } & 1 & 222 & 3,7673 & 0,63372 & \multirow{2}{*}{$\begin{array}{l}-0,951 \\
(0,342)\end{array}$} \\
\hline & & 2 & 206 & 3,8269 & 0,66235 & \\
\hline & \multirow{2}{*}{ Versengés } & 1 & 222 & 3,1997 & 0,70241 & \multirow{2}{*}{$\begin{array}{r}0,215 \\
(0,830)\end{array}$} \\
\hline & & 2 & 206 & 3,1845 & 0,76258 & \\
\hline & \multirow{2}{*}{ Együttműködés } & 1 & 222 & 4,1381 & 0,63415 & \multirow{2}{*}{$\begin{array}{l}-0,069 \\
(0,945)\end{array}$} \\
\hline & & 2 & 206 & 4,1424 & 0,64703 & \\
\hline
\end{tabular}

Láthatjuk, hogy a nem alapján képzett csoportok esetében az első és második mérés átlagértékei között a t-próba csak a férfiak polgári erény átlagértékeinél mutat szignifikáns eltérést. 


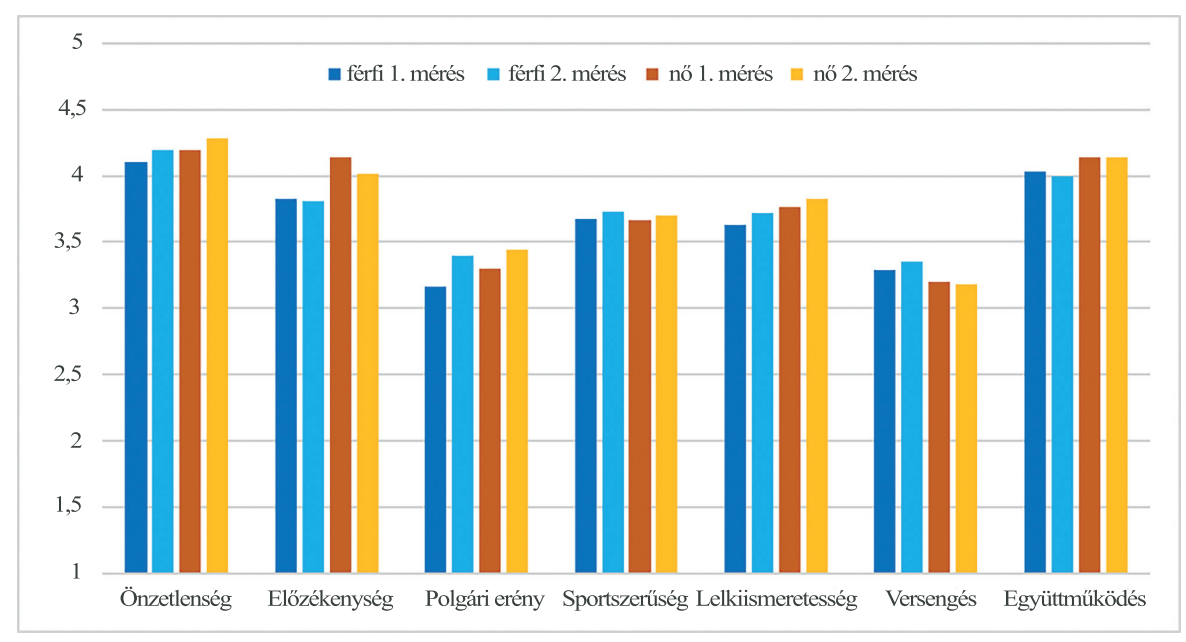

9. ábra: Két mérés összehasonlitása - nemek szerinti csoportok. Forrás: a szerzök szerkesztése

A férfiak esetében az előzékenység (3,83-ról 3,81-re) és az együttmüködés (4,036-ról 3,998-ra) mutatnak enyhe csökkenést, a többi mutató növekedést mutat: a polgári erény 3,16-ról 3,39-re, az önzetlenség 4,10-ről 4,19-re, a sportszerüség 3,67-rôl 3,73ra, a lelkiismeretesség 3,63-ról 3,72-re, és a versengés 3,29-ről 3,36-ra emelkedett.

A nők esetében szintén két csökkenő mutatót találunk, az egyik ugyanúgy az előzékenység (4,14-ről 4,02-re), ami jelentősebb a férfiaknál mérteknél, a másik mutató viszont ellentétben a férfiak csoportjával, a versengés (3,20-ról 3,19-re). Ez az eredmény feltételezhetően azt a nemi különbséget mutatja meg, amely szerint a férfiak hajlamosabbak a versengő, rivalizáló attitűdre, a nők pedig az együttmúködőre, mivel ezek a szociokulturális elvárások velük szemben. Az előzékenységben megjelenő különbség is ezt a nemhez kötött, szociálisan elvárt viselkedéseket takarhatja, amely szerint a nők magatartásukban alapvetően gyakrabban jelenik meg a másik vagy a másik személy tevékenységének figyelembevétele, annak akadályozásától való tartózkodás.

A nők csoportjánál is a többi mutató növekedést mutat: a polgári erény 3,30-ról 3,44-re, az önzetlenség 4,19-ről 4,28-ra, a sportszerüség 3,66-ról 3,70-re, a lelkiismeretesség 3,77-ről 3,83-ra, és az együttmúködés 4,138-ről 4,142-re emelkedett.

\section{Szakirány (civil/hivatásos) alapján}

A szak civil, illetve hivatásos jellege szerinti csoport-összehasonlításban az alábbi csoportátlagokat és szórásokat kaptuk. 
KOVÁCS Gábor - PESTI Tünde - TŐZSÉR Erzsébet: A hallgatói magatartásformák megjelenése...

9. táblázat: A mérésenként a szakirány szerinti csoportok átlagai és szórásai. Forrás: a szerzők szerkesztése

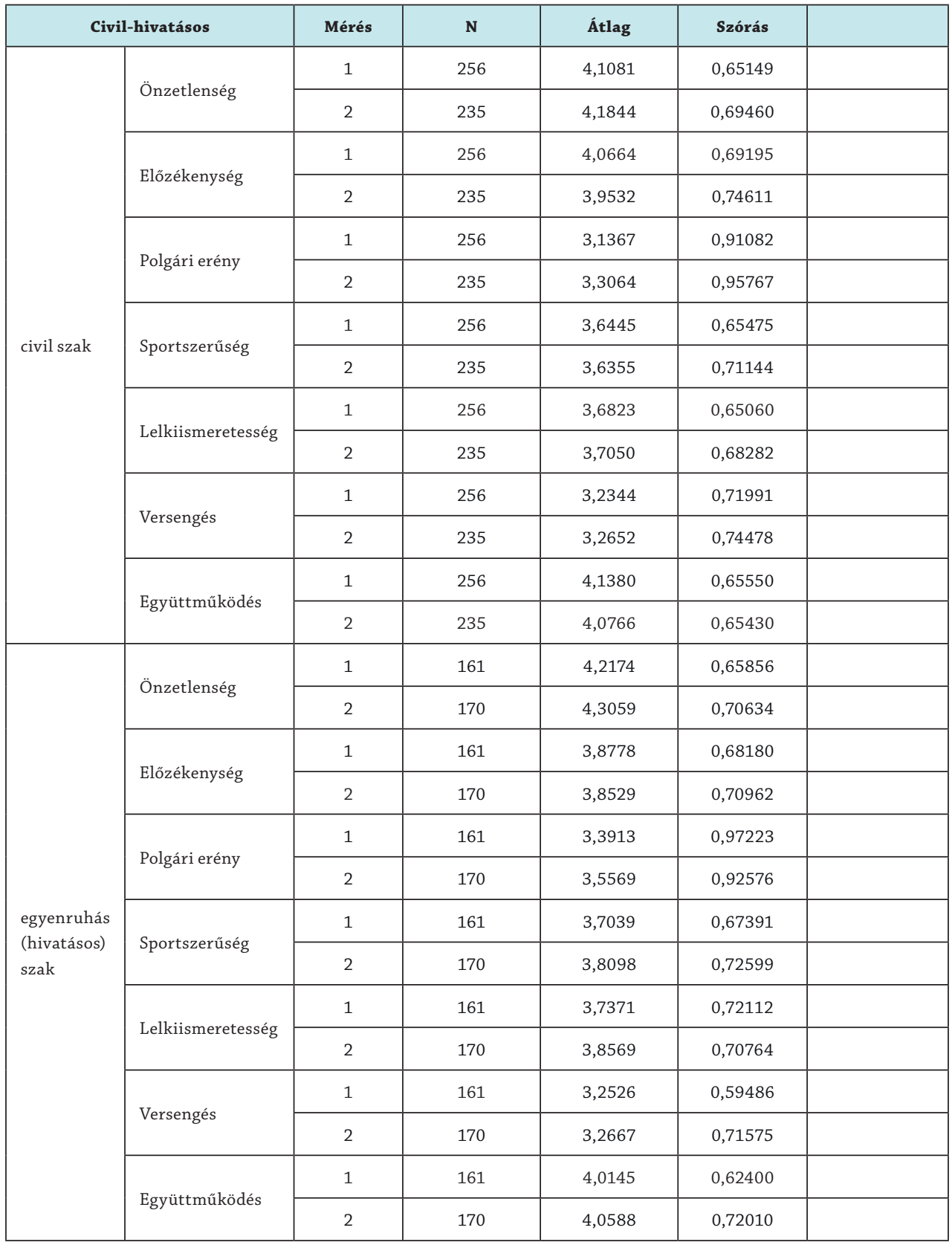




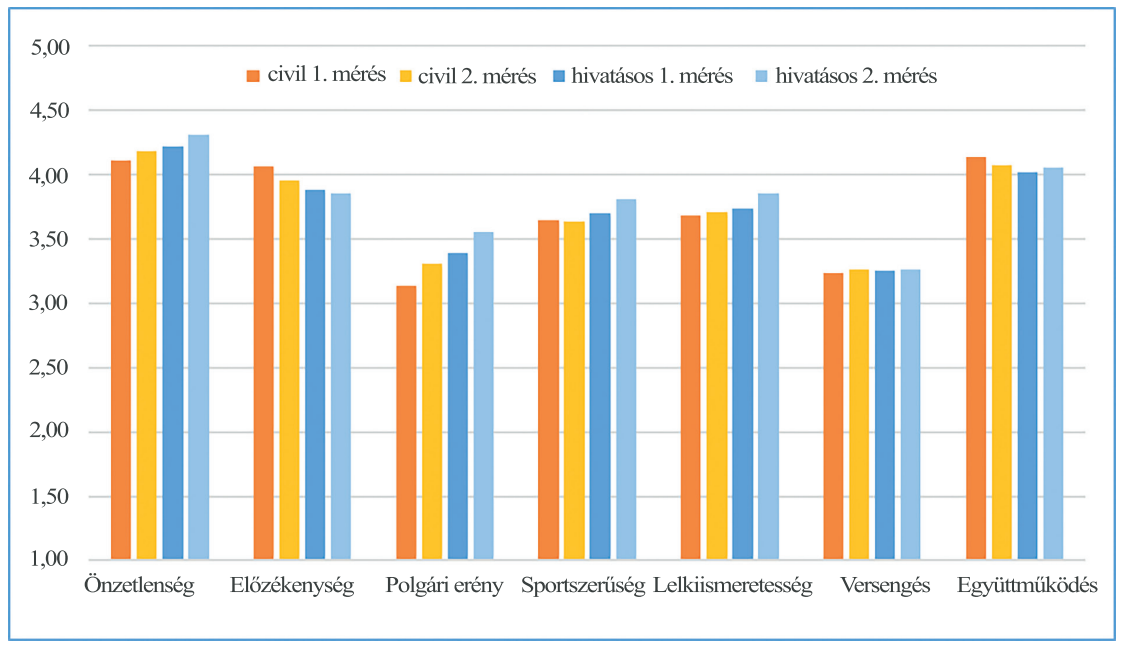

10. ábra: Két mérés összehasonlitása - hivatásos/civil csoport. Forrás: a szerzők szerkesztése

A civil szakos hallgatók esetében az előzékenység (4,07-ről 3,95-re), a sportszerűség (3,65-ről 3,64-re) és az együttmúködés (4,14-ről 4,07-re) átlaga csökkent, a többi négy faktor viszont emelkedést mutatott: a polgári erény 3,14-ről 3,31-re, az önzetlenség 4,11-ről 4,18-ra, a lelkiismeretesség 3,68-ról 3,71-re, és a versengés 3,23-ról 3,27-re emelkedett.

A hivatásos szakon tanuló hallgatók esetében egyedül az előzékenység csökkent, 3,88-ról 3,85-re. A többi hat faktor mind növekedést mutatott: a polgári erény 3,39-ről 3,56-ra, a lelkiismeretesség 3,74-ről 3,86-ra, az önzetlenség 4,22-ről 4,31-re, a sportszerüség 3,70-ről 3,81-re, és a versengés 3,26-ról 3,27-re emelkedett.

A civil $(3,14$ és 3,31$)$ és hivatásos $(3,39$ és 3,56$)$ hallgatók polgári erény átlagértékben való eltérését a hivatásos hallgatói csoport hivatásrendjük irányában meglévő elkötelezettségének tulajdoníthatjuk. Ahogy az önzetlenség esetében meglévő (civil: 4,11 és 4,18, hivatásos: 4,22 és 4,31) eltérést is magyarázhatjuk a segítő foglalkozást választók önzetlen magatartásával, ami szintén jellemzi a hivatásrendhez csatlakozókat. Ugyanakkor ezeknek ellentmondani látszik az elózékenység (civil: 4,07 és 3,95, hivatásos: 3,88 és 3,85 ) esetében meglévő eltérés a két csoport között, hiszen ez esetben a civil szakos hallgatók mutatják a magasabb átlagot, tehát ők feladat-végrehajtás során jobban figyelnek arra, hogy tevékenységük milyen hatással lesz a csoport többi tagjára. 


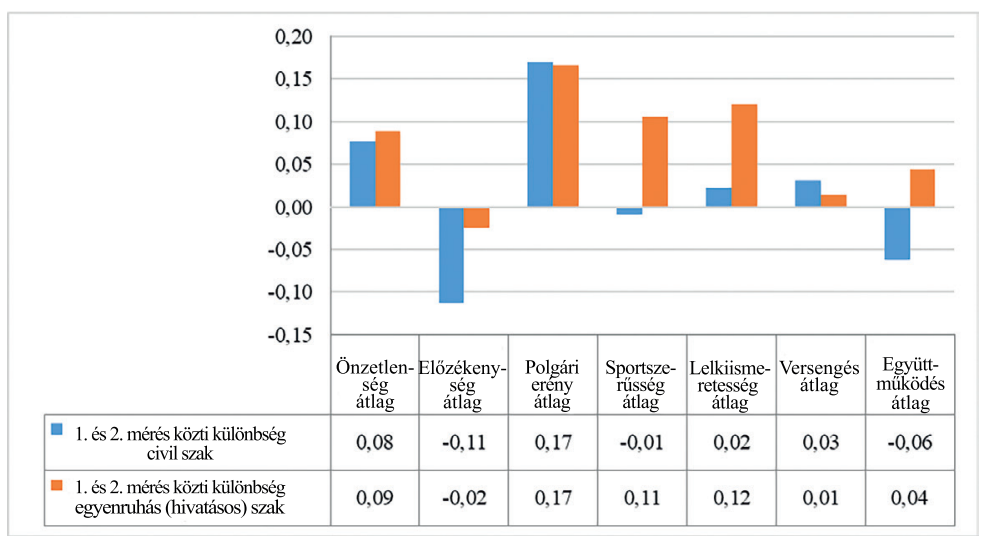

11. ábra: Az 1. és 2. mérés közötti különbség (hivatásos-civil). Forrás: a szerzők szerkesztése

A hivatásos és civil csoportok esetében a dimenziók átlagaiban bekövetkező változásokat ábrázoló diagramon látszik, hogy bár a különbségek minimálisak, a növekedés a hivatásos csoportot jellemzi inkább.

\section{Generáció alapján}

A generációs megoszlást a kutatásban részt vevők körében az alábbi táblázat mutatja (X generáció: 1965-1979, Y generáció: 1980-1994, ${ }^{26}$ Z generáció: 1995 után született hallgatók). Jól látszik a Z generáció egyértelmű túlsúlya a mintában, hiszen a nappali hallgatók tartoznak ebbe a korcsoportba.

\footnotetext{
26 A korosztály megjelölése során ötéves időintervallumok közül választhattak a hallgatók: 1965-1969, 1970-1974, 1975-1979, 1980-1984, 1985-1989, 1990-1994, 1995-1999, 2000-2004.
} 
KOVÁCS Gábor - PESTI Tünde - TŐZSÉR Erzsébet: A hallgatói magatartásformák megjelenése...

10. táblázat: Generációk megoszlása mérésenként. Forrás: a szerzők szerkesztése

\begin{tabular}{|l|l|c|c|}
\hline \multicolumn{2}{|c|}{ Mérés } & Gyakoriság & Százalék \\
\hline \multirow{4}{*}{} & X generáció & 35 & 8,4 \\
\cline { 2 - 4 } & Y generáció & 56 & 13,4 \\
\cline { 2 - 4 } & Z generáció & 326 & 78,2 \\
\cline { 2 - 4 } & Összesen & 417 & 100 \\
\hline \multirow{3}{*}{1} & X generáció & 29 & 7,1 \\
\cline { 2 - 4 } & Y generáció & 55 & 13,5 \\
\cline { 2 - 4 } & Z generáció & 323 & 79,4 \\
\cline { 2 - 4 } & Összesen & 407 & 100 \\
\hline
\end{tabular}

A korcsoportok közti különbségeket a következő táblázat mutatja.

11. táblázat: Mérésenként a generáció szerinti csoportok átlagai és szórásai. Forrás: a szerzők szerkesztése

\begin{tabular}{|c|c|c|c|c|c|}
\hline & Generáció & Mérés & $\mathbf{N}$ & Átlag & Szórás \\
\hline \multirow[t]{14}{*}{ X generáció } & \multirow{2}{*}{ Önzetlenség } & 1 & 35 & 4,4095 & 0,49893 \\
\hline & & 2 & 29 & 4,5057 & 0,45093 \\
\hline & \multirow{2}{*}{ Előzékenység } & 1 & 35 & 3,9143 & 0,68286 \\
\hline & & 2 & 29 & 3,9080 & 0,59024 \\
\hline & \multirow{2}{*}{ Polgári erény } & 1 & 35 & 3,7905 & 0,73247 \\
\hline & & 2 & 29 & 3,7701 & 0,70206 \\
\hline & \multirow{2}{*}{ Sportszerűség } & 1 & 35 & 3,9524 & 0,56094 \\
\hline & & 2 & 29 & 3,9195 & 0,56100 \\
\hline & \multirow{2}{*}{ Lelkiismeretesség } & 1 & 35 & 4,1333 & 0,44428 \\
\hline & & 2 & 29 & 4,1149 & 0,48203 \\
\hline & \multirow{2}{*}{ Versengés } & 1 & 35 & 3,2667 & 0,58745 \\
\hline & & 2 & 29 & 3,0690 & 0,57307 \\
\hline & \multirow{2}{*}{ Együttműködés } & 1 & 35 & 4,1238 & 0,56061 \\
\hline & & 2 & 29 & 4,1494 & 0,52392 \\
\hline
\end{tabular}


KOVÁCS Gábor - PESTI Tünde - TŐZSÉR Erzsébet: A hallgatói magatartásformák megjelenése...

\begin{tabular}{|c|c|c|c|c|c|}
\hline & Generáció & Mérés & $\mathbf{N}$ & Átlag & Szórás \\
\hline \multirow[t]{14}{*}{ Y generáció } & \multirow{2}{*}{ Önzetlenség } & 1 & 56 & 4,1548 & 0,71340 \\
\hline & & 2 & 55 & 4,3636 & 0,68575 \\
\hline & \multirow{2}{*}{ Előzékenység } & 1 & 56 & 3,9940 & 0,74804 \\
\hline & & 2 & 55 & 3,9152 & 0,74871 \\
\hline & \multirow{2}{*}{ Polgári erény } & 1 & 56 & 3,5357 & 0,96542 \\
\hline & & 2 & 55 & 3,6061 & 1,10571 \\
\hline & \multirow{2}{*}{ Sportszerűség } & 1 & 56 & 3,7381 & 0,70414 \\
\hline & & 2 & 55 & 3,8848 & 0,67956 \\
\hline & \multirow{2}{*}{ Lelkiismeretesség } & 1 & 56 & 3,8988 & 0,63220 \\
\hline & & 2 & 55 & 3,9333 & 0,68913 \\
\hline & \multirow{2}{*}{ Versengés } & 1 & 56 & 3,3155 & 0,57356 \\
\hline & & 2 & 55 & 3,4182 & 0,69749 \\
\hline & \multirow{2}{*}{ Együttműködés } & 1 & 56 & 4,0000 & 0,71067 \\
\hline & & 2 & 55 & 4,0000 & 0,69979 \\
\hline \multirow[t]{14}{*}{ Z generáció } & \multirow{2}{*}{ Önzetlenség } & 1 & 326 & 4,1217 & 0,65569 \\
\hline & & 2 & 323 & 4,1930 & 0,71529 \\
\hline & \multirow{2}{*}{ Előzékenység } & 1 & 326 & 4,0020 & 0,68637 \\
\hline & & 2 & 323 & 3,9123 & 0,74318 \\
\hline & \multirow{2}{*}{ Polgári erény } & 1 & 326 & 3,1237 & 0,92784 \\
\hline & & 2 & 323 & 3,3519 & 0,93491 \\
\hline & \multirow{2}{*}{ Sportszerűség } & 1 & 326 & 3,6247 & 0,65785 \\
\hline & & 2 & 323 & 3,6636 & 0,73674 \\
\hline & \multirow{2}{*}{ Lelkiismeretesség } & 1 & 326 & 3,6237 & 0,68403 \\
\hline & & 2 & 323 & 3,7141 & 0,70379 \\
\hline & \multirow{2}{*}{ Versengés } & 1 & 326 & 3,2260 & 0,69852 \\
\hline & & 2 & 323 & 3,2621 & 0,75095 \\
\hline & \multirow{2}{*}{ Együttműködés } & 1 & 326 & 4,1022 & 0,64300 \\
\hline & & 2 & 323 & 4,0764 & 0,69183 \\
\hline
\end{tabular}




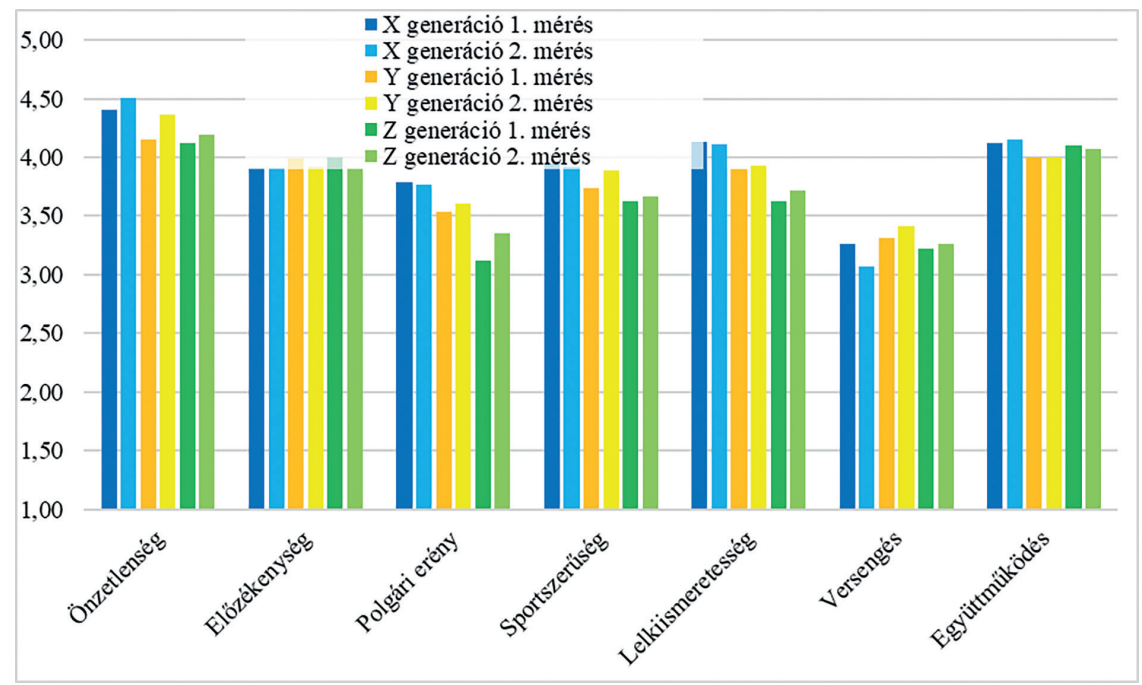

12. ábra: Két mérés összehasonlitása - X, Y és $Z$ generáció csoportjai között. Forrás: a szerzók szerkesztése

A fentiek alapján az X generáció esetében az előzékenység (3,914-ről 3,908-ra), a polgári erény (3,79-rôl 3,77-re), a sportszerűség (3,95-ről 3,92-re), a lelkiismeretesség (4,13-ról 4,12-re) és a versengés (3,27-ről 3,07-re) értékei mutattak csökkenést. Az önzetlenség (4,41-ről 4,51-re) és együttmúködés (4,12-ről 4,15-re) növekedett.

$\mathrm{Az}$ Y generáció esetében az előzékenység (3,99-ről 3,92-re) csökkenést mutat, az együttmúködés $(4,00)$ változatlan, a többi 5 faktor pedig emelkedést mutat az első méréshez képest: az önzetlenség (4,16-ról 4,36-ra), a sportszerüség (3,74-ről 3,88-ra), a polgári erény (3,54-ről 3,61-re), a lelkiismeretesség (3,90-ról 3,93-ra), a versengés pedig (3,32-rôl 3,42-re) nőtt.

A Z generáció esetében az előzékenység (4,00-ról 3,91-re) és az együttmüködés (4,10-ről 4,08-ra) értékei mutattak csökkenést, a többi faktor azonban emelkedést mutatott az alábbi sorrendben: polgári erény (3,12-rôl 3,35-re), lelkiismeretesség (3,62-ről 3,71-re), önzetlenség (4,12-ről 4,19-re), sportszerűség (3,62-ről 3,66-ra), versengés (3,23-ról 3,26-ra).

Az idősebb generáció $(X)$ felől a fiatalabb $(Z)$ irányába haladva egyfajta tendenciaszerú csökkenést láthatunk: az önzetlenség (X: 4,41-ről 4,51-re, Y: 4,16-ról 4,36-ra, Z: 4,12-ről 4,19-re), a polgári erény (X: 3,79-ről 3,77-re, Y: 3,54-ről 3,61-re, Z: 3,12-ről 3,35-re), a sportszerúség (X: 3,95-ról 3,92-re, Y: 3,74-ról 3,88-ra, Z: 3,62-ról 3,66-ra) és a lelkiismeretesség (X: 4,13-ról 4,12-re, Y: 3,90-ről 3,93-ra, Z: 3,62-ről 3,71-re) dimenzióiban. Ezek a különbségek a generációk közti eltéréseket mutatják, feltételezve, hogy a korábban ismertetett elméleti jellemzések valóban kihatással vannak a generációhoz tartozók magatartására. 


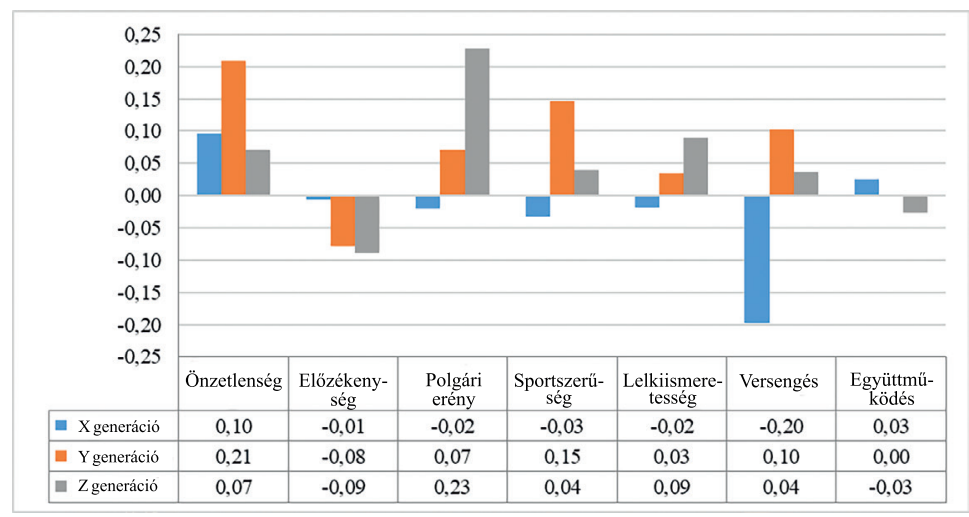

13. ábra: Mérések közötti eltérések generációknál. Forrás: a szerzők szerkesztése

A generációk közti különbségek oka feltételezhetően az, hogy alapvetően magasabb OCB-értékeket mutattak az idősebb (X) generáció képviselői mint a minta legfiatalabbjai (Z), hiszen az X generációhoz általában már a közszolgálatban dolgozók kerültek, akik alapvetően magas OCB-indexekkel rendelkeztek.

A Z generáció esetében a polgári erény (3,12-ről 3,35-re) emelkedett a legnagyobb mértékben, amely valamilyen szinten megfeleltethető a szervezethez való kötődésnek, amely a már dolgozók esetében valószínúleg kialakult, a nappalis diákoknál viszont a gyakorlat ebben jelentős szerepet tölthet be. Növekedést mutatott a sportszerúség és az önzetlenség is, vagyis a nappalis hallgatókat a gyakorlat a szervezeti kultúra elsajátításában jelentősen segítheti.

\section{Az eredmények összefoglalása, következtetések}

Vizsgálatunk során a szervezeti önkéntes magatartás öt és a versengés-együttmúködés két dimenziójának hallgatók körében történő felmérése történt normál működésmód esetén és kooperatív helyzetben, a KKGY alatt. Ez a viselkedés az oktatási folyamat során nem kerül felszínre, a KKGY viszont lehetőséget ad arra, hogy feladatmegoldáskor, illetve probléma kezelése során a szervezeti önkéntes magatartás formáinak megjelenési gyakoriságát vizsgáljuk a részt vevő hallgatók esetében.

Mindkét mérési helyzetben - normál működésmód, együttmúködési helyzet - az alábbi sorrendiséget tudjuk felállítani a szervezeti önkéntes magatartás dimenzióinak megjelenési gyakoriságaiban:
1. önzetlenség,
2. előzékenység,
3. lelkiismeretesség,
4. sportszerüség,
5. polgári erény. 
Az együttmúködés- és versengésmutatókat figyelembe véve az együttműködés magasabb értéket mutatott mind az első, mind pedig a második mérés esetében.

Egyetlen dimenziónál, a polgári erény esetében tapasztaltunk szignifikáns eltérést a gyakorlat előtt és után kapott értékek esetében, a többi dimenzió esetében nem volt szignifikáns a különbség. Az alábbi esetekben mutatkozott növekedés az első és a második mérés viszonylatában a dimenzióknál:

1. önzetlenség,

2. lelkiismeretesség,

3. sportszerüség,

4. polgári erény

5. versengés.

A fentiekből úgy tűnik, hogy a feladatmegoldási helyzet kedvez az önzetlenség, lelkiismeretesség, sportszerűség és polgári erény magatartásmódjai megjelenésének.

Kismértékű csökkenést tapasztaltunk az előzékenység és az együttmúködés esetében. Ennek a két mutatónak a csökkenése feltétlenül együtt értelmezendő azzal a ténnyel, hogy az első mérés alkalmával is elég magas értékek születtek, és a válaszgyakoriságok is a szélső értékek felé húztak mindkét mérési helyzetben. Ugyanakkor a feladatmegoldási szituáció mindenképp egyfajta célorientáltságot hoz felszínre, amihez képest a társakra való figyelés kissé háttérbe szorul.

Az előzékenység magatartásformáit figyelembe véve azt tapasztaltuk, hogy a hallgatók a KKGY keretein belül az egymással történő együttműködés során kevésbé figyeltek arra, hogy milyen hatással van saját feladat-végrehajtásuk a többiekére.

A versengés a KKGY előtt és alatt is alacsonyabb értéket mutatott az együttmúködés értékénél, tehát a hallgatók többsége inkább együttműködő, mint versengő, mindkét mérési szituációban.

A mérés eredményeinek tükrében a versengés tekintetében az első és második mérés között enyhe növekedés tapasztalható a hallgatók átlagát tekintve, de még így is a középső érték felé tendál, a növekedésnek az oka a feladathelyzet melletti elköteleződésből fakadó célorientáltságot tükrözheti.

Fő hipotéziseinkre adott válaszok a felmérés eredményeinek tükrében:

- Hipotézis: a gyakorlatot megelőző és az azt követő két mérés értékei között eltérést tudunk kimutatni. Tehát a gyakorlaton részt vevő hallgatók viselkedésének változása mindegyik dimenzióban kimutatható - pozitív irányban.

- Bár eltéréseket találtunk, és a legtöbb érték esetében ez növekedést jelentett, de ezek a különbségek nem voltak szignifikánsak, így azokról csak tendenciaszinten tehettünk megfogalmazásokat.

- Hipotézis: A csoportok között (nem, szak, korcsoport) eltérés lesz kimutatható, illetve a változás mértéke is eltérő lesz a csoportok esetében az első és második mérés értékei között. A gyakorlatot megelőzően is eltérés lesz a csoportok (hivatásos/civil, férfi/nő, generációk) között, illetve a változás mértéke is eltér majd (hivatásos/civil). 
Szintén voltak különbségek a csoportok között, mindhárom (hivatásos/civil, férfi/nő, generációk) csoportbontásban, de azok nem szignifikánsak. A csoportok két mérés között mutatott eltérései szintén nem szignifikánsak, így a csoportok eltérésérôl és az értékeik változásáról is csak tendenciaszinten nyilatkozhattunk.

A hallgatók átlagát tekintve és a kutatás eredményeit figyelembe véve azt feltételezzük, hogy a különböző szervezetekbe kerülő hallgatók törekedni fognak a feladatok pontos, lelkiismeretes végrehajtására, azonosulnak a szervezettel, önzetlenül segítik társaikat, az együttmúködés lesz a fő motívum.

A feladatok végrehajtása során viszont a célorientáltság, az eredmények eléréséhez csökkenni fog az előzékenység a csoport tagjaival szemben. Ezzel a tendenciával a vezetônek tisztában kell lennie, és az így esetlegesen gyakoribban megjelenő konfliktushelyzeteket kezelnie szükséges.

\section{Befejezés}

A Nemzeti Közszolgálat Egyetem hitvallása a minőségre történő törekvés az egyetemi élet minden területén. Ebbe beletartozik a hallgatók gyakorlati felkészítése, az új oktatási módszerek alkalmazása, a hatékony és interaktív oktatási és tanulási módszerek alkalmazása a generációs sajátságok figyelembevételével.

Az évente megszervezésre kerülő Közös Közszolgálati Gyakorlat ennek a törekvésnek a kitûnő példája, ahol a különböző hivatásrendek hallgatói egy közös célért küzdenek, a fenyegető veszély elhárítása érdekében tevékenykednek - „együtt múködnek” modellezve az államigazgatási szervezet teljes müködési rendszerét.

A tanulmány ennek a közös tevékenységnek a hátterét kutatja, azt hogy hogyan milyen az egyén közösségi magatartása a gyakorlatot megelőzően, és hogyan fejlődik az egyének magatartása a gyakorlat alatt és azt követően. A kutatás egyértelmúen bizonyítja a gyakorlat levezetésének hasznos hatásait. Egy folyamat kezdetén vagyunk, azt tervezzük, hogy a jövőben levezetendő gyakorlatokon is megmérjük a tanulmányban leírt tulajdonságok változásait.

\section{IRODALOMJEGYZÉK}

Endrődi István (2014): „Végvár 2014”: A Nemzeti Közszolgálati Egyetem 2014. évi Közös Közszolgálati Gyakorlat Katasztrófavédelmi Intézet részletes és kiegészítő feladatai (oktatói példány). Budapest, Nemzeti Közszolgálati Egyetem.

Endrődi István - Ambrusz József - Muhoray Árpád (2016): A Nemzeti Közszolgálati Egyetem Közös Közszolgálati Gyakorlatának a „Vihar 2016” összefoglalása, következtetései, Védelemtudomány, 1. évf. 4. sz. 241-270. Forrás: www.vedelemtudomany.hu/articles/16-endrodi-ambrusz-muhoray. pdf (2019. 10. 01.)

Hülvely Lajos szerk. (2014): „Végvár 2014”: A Nemzeti Közszolgálati Egyetem 2014. évi Közös Közszolgálati Gyakorlat Közigazgatás-tudományi Kar részletes és kiegészítö feladatai (oktatói példány). Budapest, Nemzeti Közszolgálati Egyetem. Forrás: http://m.ludita.uni-nke.hu/repozitorium/bitstream/handle/11410/10428/Teljes\%20sz\%C3\%B6veg\%21? sequence=1\&isAllowed=y (2019. 10. 01.) 
Klein Sándor (2016): Vezetés- és szervezetpszichológia. Budapest, Edge 2000 Kft.

Kovács Gábor (2013): Vezetés- és szervezéselméleti kérdések gyakorlati megoldásai a Nemzeti Közszolgálati Egyetem 2013. évi Közös Közszolgálati Gyakorlatán. In Gaál Gyula - Hautzinger Zoltán szerk.: Pécsi Határör Tudományos Közlemények XIV. Tanulmányok „A változó rendészet aktuális kihívásai" címü tudományos konferenciáról. Pécs. 79-86.

Kovács Gábor szerk. (2017): Közszolgálati müveletirányitási rendszerek: A Közös Közszolgálati Gyakorlat Elméleti Alapjai. Budapest, Dialóg Campus Kiadó.

Kovács Gábor (2018): A hatékony vezetői teljesítmény fokozásának eszközei és módszerei a rendészeti szervezetekben. In Gaál Gyula - Hautzinger Zoltán szerk.: Pécsi Határör Tudományos Közlemények XX. A XXI. század biztonsági kihívásai. Pécs. 135-146.

Kovács Gábor - Ambrusz József szerk. (2018): „Integrált védelem 2018”: A Nemzeti Közszolgálati Egyetem közös közszolgálati gyakorlat alap- és inditó feladata. (oktatói példány) Budapest, Nemzeti Közszolgálati Egyetem.

Kovács Gábor - Ambrusz József szerk. (2019): „Vírus 2019”: A Nemzeti Közszolgálati Egyetem közös közszolgálati gyakorlat alap- és indító feladata. (oktatói példány) Budapest, Nemzeti Közszolgálati Egyetem.

Kovács Gábor - Téglási József - Hülvely Lajos - Horváth Tibor - Varga János - Endrődi István Muhoray Árpád - Kónya József - Orosz László - Marsai Viktor - Horváth Tibor - Hannig Zsolt - Várhegyi Katalin (2017): „Vándor 2017”: A Nemzeti Közszolgálati Egyetem közös közszolgálati gyakorlat alap-és indító feladata. (Hallgatói példány) Budapest, Nemzeti Közszolgálati Egyetem.

Kovács Gábor - Téglási József - Hülvely Lajos - Varga János - Endrődi István - Horváth Tibor Peleskey György (2014): „Végvár 2014”: A közszolgálati gyakorlat koncepciójának és az indító feladatnak a kidolgozása. (oktatói példány) Budapest, Nemzeti Közszolgálati Egyetem.

Kovács Gábor - Pesti Tünde - Tőzsér Erzsébet (2019): „VÍRUS 2019” - A Közös Közszolgálati Gyakorlat szerepe a hallgatók szervezeti önkéntes magatartásának kialakulásában - kutatási jelentés. Budapest, NKE belső dokumentum.

Meretei Barbara (2017): Generációs különbségek a munkahelyen-szakirodalmi áttekintés. Vezetéstudomány, 48. évf. 10. sz. 10-18. DOI: https://doi.org/10.14267/VEZTUD.2017.10.02

Organ, Dennis W. (1988): Organisational citizenship behavior: The good soldier syndrome. Lexington, Lexington Books,

Organ, Dennis W. (2018): The Roots of Organizational Citizenship Behavior. In Podsakoff, Philip M. - MacKenzie, Scott B. - Podsakoff, Nathan P. eds.: The Oxford Handbook of Organizational Citizenship Behavior. New York, Oxford University Press Inc. 7-19.

Singh, Akhilenda Kumar - Singh, A. P. (2009): Organizational Citizenship Behaviour: A Conceptual Analysis. In Singh, Shyodan ed.: Organizational Behaviour. Global Vision Publishing House. 227-244.

Tari Annamária (2010): Y generáció: klinikai pszichológiai jelenségek és társadalom-lélektani szempontok az információs korban. Budapest, Jaffa Kiadó Kft.

Tari Annamária (2011): Z generáció: klinikai pszichológiai jelenségek és társadalom-lélektani szempontok az információs korban. Budapest, Tericum Kiadó Kft.

Tari Annamária (2018): Generációk és változások... címú előadás. Forrás: http://tmte.hu/_userfiles_/ tmte/KGY70_Tari_eloadas_20180517.pdf (2019.10. 01.)

Téglási József (2014):,Végvár 2014”: A Nemzeti Közszolgálati Egyetem 2014. évi közös közszolgálati gyakorlat Hadtudományi és Honvédtisztképző Kar részletes feladatai. (Hallgatói példány) Budapest, Nemzeti Közszolgálati Egyetem.

Törőcsik Mária - Szűcs Krisztián - Kehl Dániel (2014): How Generations Think: Research on Generation Z. Acta Universitas Sapientiae, Communicatio, No. 1. 23-45. 


\title{
ABSTRACT \\ Students behaviour patterns and the process of their change at the "VIRUS 2019" Joint Public Service Practice at the National University of Public Service
}

\author{
KOVÁCS Gábor - PESTI Tünde - TŐZSÉR Erzsébet
}

Every year, the National University of Public Service organizes the Joint Public Service Practice for its students. The Practice allowed the measurement of Organisational Citizenship Behaviour (OCB) dimensions and of the skills of cooperation which are essential for a modern public administration. The longitudinal research took place between January and May of 2019. In the frame of the research we examined the total number of students participating in the practice (886 people). The following groups were studied: male-female, professional (law enforcement)-civil, generations $(X, Y, Z)$. During the research the frequency of OCB dimensions, cooperation and competition behaviour patterns were measured by using of questionnaires. Collected data sets were analysed by SPSS 25 software. Results mostly did not show significant differences in behaviour patterns before and during the practice however the differences were detectable. The biggest differences were measured between the generations and at the OCB dimension "Courtesy".

Keywords: Joint Public Service Practice, Organisational Citizenship Behaviour (OCB), cooperation, public administration, law enforcement, generations 